\title{
Anaphylaxis to beetroot (Beta vulgaris): a case report
}

\author{
Lucila Camargo Lopes de Oliveira" ${ }^{*}$, Isabel Ruguê Genov ${ }^{1}$, Elza do Carmo Cabral ${ }^{2}$, Yara Arruda MF Mello², \\ Márcia Carvalho Mallozi ${ }^{1}$, Dirceu Solé \\ From Food Allergy and Anaphylaxis Meeting 2011 \\ Venice, Italy. 17-19 February 2011
}

\section{Background}

Allergy to beetroot is very rare. Until now only a few reports about asthma and rhinoconjunctivitis induced by inhaling the vapor of cooked beet have been reported. Oral food challenging on any non-toxic adverse reaction to food may be important.

\section{Methods}

Record review.

\section{Results}

LSJ, a 13-years old Brazilian girl has complained of urticaria and asthma about 40 minutes after ingesting salty boiled beetroot on a meal. She had a previous history of wheezing until she was five years old. Seric-specific IgE to beetroot and other foods were negative, as well as to latex, bee, wasp and ant. She was sensitized only to house dust mite. Boiled and raw beetroot prick to prick were also negative (histamine resulted $4 \mathrm{~mm}$ ) but a food challenge with boiled beetroot resulted positive after 30 minutes with generalized hives, throat tightness and bronchospasm. Symptoms were controlled with intramuscular epinephrine, inhaled beta-2-agonists and intravenous corticosteroids. She was advised for a diet free of beetroot and she has had no symptoms for the last 8 months.

\section{Conclusions}

Although beetroot sensitization was not proven, one must still consider in this case an IgE-mediated reaction against a neoallergen promoted by protein digestion or food intolerance. In both situations a food challenge is

'UNIFESP, São Paulo, Brazil

Full list of author information is available at the end of the article necessary. Discharging patients based only on a negative sensitization investigation may be life threatening.

\section{Author details}

'UNIFESP, São Paulo, Brazil. ${ }^{2}$ Clínica de Alergia São Paulo, São Paulo, Brazil.

Published: 12 August 2011

doi:10.1186/2045-7022-1-S1-P51

Cite this article as: Lopes de Oliveira et al:: Anaphylaxis to beetroot (Beta vulgaris): a case report. Clinical and Translational Allergy 2011 1(Suppl 1): P51.
Submit your next manuscript to BioMed Central and take full advantage of:

- Convenient online submission

- Thorough peer review

- No space constraints or color figure charges

- Immediate publication on acceptance

- Inclusion in PubMed, CAS, Scopus and Google Scholar

- Research which is freely available for redistribution

Submit your manuscript at www.biomedcentral.com/submit
( Biomed Central
C Biomed Central

(0) 2011 Lopes de Oliveira et al; licensee BioMed Central Ltd. This is an open access article distributed under the terms of the Creative Commons Attribution License (http://creativecommons.org/licenses/by/2.0), which permits unrestricted use, distribution, and reproduction in any medium, provided the original work is properly cited. 